\title{
Schinus terebinthifolius raddi (Aroeira) and Orbignya phalerata mart. (Babassu) effect in cecorrahphy healing in rats $^{1}$
}

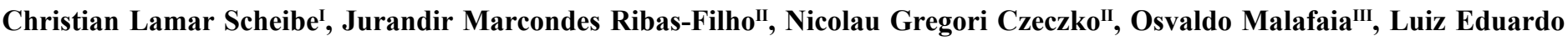 \\ Durães Barboza', Fernanda Marcondes Ribas ${ }^{\mathrm{IV}}$, Eduardo Wendler ${ }^{\mathrm{IV}}$, Orlando Torres ${ }^{\mathrm{v}}$, Fernanda Christo Lovato ${ }^{\mathrm{VI}}$, João \\ Guilherme Seifert Scapinivi
}

DOI: http://dx.doi.org/10.1590/S0102-865020160060000007

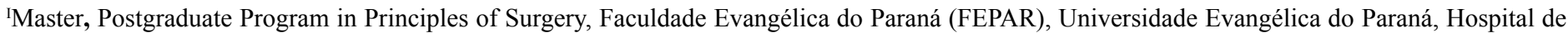
Curitiba, Medical Research Institute, Curitiba-PR, and Hospital São Domingos, Sao Luis-MA, Brazil. Conception, design, intellectual and scientific content of the study.

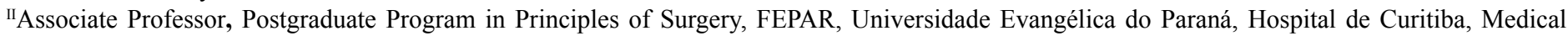
Research Institute, Curitiba-PR, Brazil. Scientific and intellectual content of the study, interpretation of data, critical revision.

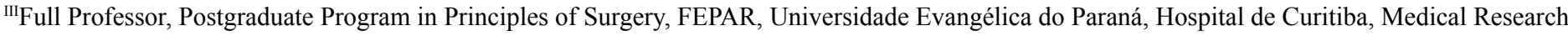
Institute, Curitiba-PR, Brazil. Scientific and intellectual content of the study, interpretation of data, critical revision.

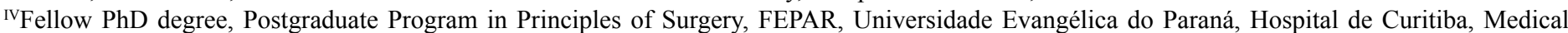
Research Institute, Curitiba-PR, Brazil. Conception, design, intellectual and scientific content of the study.

${ }^{v} \mathrm{PhD}$, Department of Surgery, Universidade Federal do Maranhão, Sao Luis-MA, Brazil. Conception, design, intellectual and scientific content of the study.

${ }^{\mathrm{VI}}$ Graduate student, PIBIC, Postgraduate Program in Principles of Surgery, FEPAR, Universidade Evangélica do Paraná, Hospital de Curitiba, Medical Research Institute, Curitiba-PR, Brazil. Acquisition of data.

\section{ABSTRACT}

PURPOSE: To evaluate the effect of Schinus terebinthifolius Raddi (aroeira) and Orbignya phalerata Mart. (babassu) in the healing process of cecorrhaphy in rats.

METHODS: Fifty four rats were used, distributed into three groups randomly: aroeira, babassu and control, which were divided into three subgroups (six animals) according to the time of the deaths (7, 14, 21 days). All underwent the same surgical procedure, cecotomy and cecorrhaphy. The animals in group aroeira and babassu received daily dose of $100 \mathrm{mg} / \mathrm{kg}$ of hydroalcoholic extract and $50 \mathrm{mg} / \mathrm{kg}$ of aquous extract respectively, by gavage. The control group received only saline solution. The parameters evaluated were: macroscopic changes, ,resistance test to air insufflations and histological changes.

RESULTS: All animals showed good healing without infection. All groups presented adhesions between cecum and neighboring organs. The resistance test insufflating of atmospheric air showed progressive increase of pressure according to the days in the aroeira group, and decrease in babassu group, without significant difference. Microscopy showed significant difference in the polymorphonuclear, hyperemia, angiogenesis, fibroblast proliferation and collagen histological variables in the $14^{\text {th }}$ day.

CONCLUSION: Hydroalcoholic extract of aroeira and the aqueous extract of babassu favored the healing process in cecorrhaphy in rats.

Key words: Wound Healing. Colon. Phytotherapy. Plant Extracts. Rats. 


\section{Introduction}

The healing process is a biological, chemical and physical complex event involving inflammation, chemotaxis, proliferation, differentiation and cellular remodeling. It can be divided into three phases: $1^{\text {st }}$ or exudative inflammation; $2^{\text {nd }}$ or proliferative/ fibroblastic (granulation tissue with deposition of extracellular matrix); $3^{\text {rd }}$ or remodeling/maturation ${ }^{1-6}$. The knowledge of each of these stages is important to guide appropriate adjuvant therapy to improve biological reaction ${ }^{6}$.

The key factors for good healing in the gastrointestinal tract are closely related to the layer of collagen in the submucosa, good vascularization of the bowel edges, contamination by intestinal contents, submucosal suture, and delicate handling of wounded tissues ${ }^{7}$.

The application of medicinal plants in healing of colonic lesions, as well as other tissues and organs, has been demonstrated in several studies ${ }^{8-10}$. Brazil has the largest diversified forest reserve on the planet. Many species are used for medicinal purposes with low or no evidence of its properties ${ }^{11}$. The use of medicinal plants is not restricted to rural areas or regions devoided of medical and pharmaceutical care. They are also used extensively in the urban environment as an alternative or supplement to habitual medication. However, most of the data regarding the use of these plants is still empirical, based on popular culture. The interest in discovering new substances stimulated scientists from different areas to look for flora with medicinal properties normally used by the population. This fact can be observed in some studies that assessed the potential healing of plants capable of stimulating surgical repair ${ }^{12}$

The medicinal plant potentiality is based on the presence of active principles able to produce various pharmacological effects. Between the bioactive substances that can be found in different parts of a plant are highlighted alkaloids, saponins, tannins, glycosides, flavonoids and oils.

The pepper tree (Schinus terebinthifolius Raddi) is an Anacardiaceae native in Peru, kingdom Plantae, class Magnoliopsida, order Sapindales, family Arecaceae, genus Schinus, Schinus terebinthifolius species, with geographic distribution throughout the coastal Northeast, Southeast, South and Central Western Brazil, and natural location in the states of Paraná, Santa Catarina and Rio Grande do Sul. Known as toxic plant, is widely used in folk medicine, especially in the treatment of inflammatory processes in general. Many of its properties can be assigned to different polyphenols (defense mechanism), which are distributed unevenly in the various plant organs, such as bark, leaves, flowers, fruits and seeds ${ }^{13}$. Many studies have been done with aroeira: analysis of the morphology and anatomy of its seeds, bark and leaves; chemical and microscopic examination; bark development; fruits; mutagenic effect; antibiotic; antioxidant; antiulcerogenic; fungicide; as well as healing process on colon, bladder, skin, line alba and stomach ${ }^{8-10,14-16}$.

Babassu (Orbignya phalerata) is another plant characterized by being a palm tree of kingdom Plantae, Magnoliophyta phylum, class Liliopsida, order Arecales, family Arecaceae, genus Orbignya, Orbignya phalerata species. It is found more frequently in the North, Northeast and Midwest regions of Brazil, and $54.2 \%$ of them are located in the state of Maranhão. It consists of four parts: exocarp, mesocarp, endocarp and seeds. The powder is derived from babassu mesocarp and features some proven anti-inflammatory and analgesic properties. Its popular use is indicated in the dysmenorrhea, ulcers, tumors, rheumatism, constipation, colitis and obesity ${ }^{17}$.

This study aims to analyze the healing effect of the hydroalcoholic extract of aroeira and babassu aqueous extract administered by gavage in cecorrhaphy in rats.

\section{Methods}

This study was performed at Laboratory of Experimental Surgery, Universidade Federal do Maranhão and Mother and Child University Hospital, and was approved by the Ethics Committee of the State University of Maranhão under no 038/2012.

Forty four Wistar rats were used (Rattus norvegicus albinus, Rodentia mammalia) weighing on average $271.3 \mathrm{~g}$, conditioned, acclimatized and fed by the standard form for the species. They were randomized during surgery in three groups of 18: aroeira group (GA), babassu group (GB) and control group (GC). Each group was divided into three subgroups of six animals, dead on the $7^{\text {th }}, 14^{\text {th }}$ and $21^{\text {st }}$ days after the procedure.

\section{Hydroalcoholic extract of aroeira}

It was prepared at the Laboratory of Natural Products of Chemistry Department, FEPAR, Center of Exact Sciences and Technology from the dried inner bark of a single mature tree registered at Atico Seabra Herbarium of the same university named with the number 488. The guidelines of the Brazilian Pharmacopoeia II were adopted following the known methodology to prepare the extract. The plant material ( $8 \mathrm{~kg}$ of dry bark) was placed to dry at room temperature, crushed with knife and placed for $24 \mathrm{~h}$ in oven at temperature between $45-50^{\circ} \mathrm{C}$ to remove 
moisture. It was then subjected to the milling process to obtain the powder which resulted in $2.400 \mathrm{~g}$. This amount was deposited in a glass container with addition of $70 \%$ alcohol solution at a ratio of 1:3 powder. The resulting mixture was left for $12 \mathrm{~h}$ and stirred for 5 min every $2 \mathrm{~h}$; then, through two simple filtration under reduced pressure in a cotton glass funnel, was obtained $3450 \mathrm{ml}$ of purple crude extract. The residual powder was discarded. This extract was concentrated on a rotary evaporator under reduced pressure at temperature between $55^{\circ} \mathrm{C}$ and $60^{\circ} \mathrm{C}$ for complete removal of solvent forming a paste of $596.85 \mathrm{~g}$, from which was withdrawn a sample (2.8 g) of the hydroalcoholic crude extract (ethanol) diluted in $28 \mathrm{ml}$ saline solution resulting in concentration of $100 \mathrm{mg} / \mathrm{ml}$.

\section{Aqueous extract of babassu}

The babassu mesocarp was obtained from mature coconut that felt naturally on the ground. After drying for three days, it was placed in oven with temperature of $45-50^{\circ} \mathrm{C}$ for $24 \mathrm{~h}$ to remove the moisture and through grinding process was obtained a powder. To obtain the aqueous extract was used $10 \mathrm{~g}$ of powder, diluted with $400 \mathrm{ml}$ of distilled water resulting in a concentration of $25 \mathrm{mg} /$ $\mathrm{ml}$. This final extract was placed in a glass in a refrigerator at a constant temperature of $10^{\circ} \mathrm{C}$.

\section{Operative procedure}

Before anesthetic induction, the animals were weighed using a digital electronic scale; all of them, but one, were identified on their tails using colored dermographic markers (black, purple, blue, green and red). After seven acclimatization days, they were carried out to surgery preceded by food suspension of $6 \mathrm{~h}$, but with free access to water. Intramuscular anesthesia with $20 \mathrm{mg} / \mathrm{kg}$ ketamine hydrochloride $5 \%$ and $10 \mathrm{mg} / \mathrm{kg}$ xylazine $2 \%$ was used in all animals

After anesthesia, they were submitted to ventral abdominal epilation followed by site disinfection with povidoneiodine solution and sterile fenestrated drape covering of area to be operated. No bowel or antibiotic preparation was performed. Median longitudinal laparotomy was carried out over $3 \mathrm{~cm}$ caudally with exposure, identification and exteriorization of the cecum, in which was held a $1 \mathrm{~cm}$ long transverse incision in the anti-mesenteric border, followed by a suture in full single plane with inversion of the mucosa with blue monofilament polypropylene 6-0. Four separate sutures were done with knots out from the intestinal lumen and overlapping the edges of the cecum. Thereafter the abdominal wall synthesis was performed in two layers with 5-0 monofilament nylon sutures, and subsequent daily IM analgesia with Dipyrone ( $25 \mathrm{mg} / \mathrm{kg} / \mathrm{dose}$ ) for five days.

\section{Postoperative}

After anesthetic recovery, the animals were randomly divided into three groups of 18 . The GA received by gavage 100 $\mathrm{mg} / \mathrm{kg}$ of aroeira, GB $50 \mathrm{mg} / \mathrm{kg}$ of babassu oil and the same amount of saline solution $0.9 \%$ in the GC, with daily administration.

After gavage, the animals were accommodated in cages containing six animals each, according to the groups and date of death. Clinical evaluation (surgical site, motor activity, provision for food), specific protocol filling, body weight (even in the scheduled death day) were noted down daily. The animals had free access to water and standard chow until the death day.

\section{Macroscopic evaluation}

After the scheduled death of the animals, the surgical scars were inspected looking for signs of infection, dehiscence of the wall, hematoma and abscess. Then, laparotomy was performed with two parallel transverse incisions (cranial and caudal) and a 1 $\mathrm{cm}$ left paramedian one, parallel to the median and perpendicular to the transverse incisions. Abdominal findings suggestive of infection, collections, fistulae and adhesions by Nair score were inspected. Surgical specimens were removed $2 \mathrm{~cm}$ above and below the suture (cecum, ascending colon and terminal ileum), not undoing the structures and organs attached to it in order to not compromise the inflation test. The specimen, after being washed with water, was identified individually with the animal number and subgroup, and then referred to inflation resistance by air insufflation test (Figure 1).

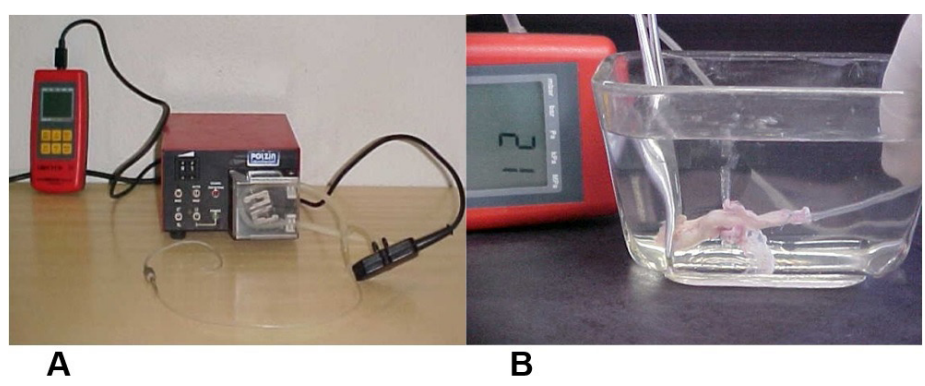

FIGURE 1 - Resistance to air insufflations. A) Probe Polzin ${ }^{\circledR}$ conected to silicone catether; B) Clear glass container with running water showing the moment of rupture of colonic anastomosis, evidenced by water bubbling with the pressure break marked in $\mathrm{mmHg}$. 


\section{Histological evaluation}

After insufflation test, surgical specimens containing colonic segment involving the suture line were fixed in a polystyrene plate and sent for standard hematoxylin-eosin and Masson's trichrome staining, evaluated by the same pathologist, blinded to the group identification. The data were classified according to the intensity transformed into quantitative variables by a score index given to histological findings ( 0 -absent, 1-mild, moderate-2 and severe-3). The presence of polymorphonuclear, vascular congestion and edema were indicative of acute inflammation (acute phase). The presence of mononuclear cells, angiogenesis, fibroblast proliferation, fibrosis (collagen deposition) and collagen were indicative of chronic inflammation (chronic phase).

\section{Statistical analysis}

Data were analyzed using the statistical program SPSS 20.0 Statistics $^{\circledR}$ (2011). Initially, the numerical variables were assessed using the normality of Liliefors test, and was found that none had a normal distribution. Therefore, these variables were evaluated in relation to the effect of group and days within each group using the Kruskal Wallis and post hoc Dunn tests. In histological variables and the degree of adherence effect of group within each day and the day within each group were also performed by these tests. For the association of the variables of the macroscopic evaluation and the rupture site the chi-square and Pearson tests were used. In all, the level of significance $(\alpha)$ was $5 \%$, which is considered significant when $\mathrm{p}<0.05$.

\section{Results}

The surgeries of all animals were uneventful and there were no deaths. The daily clinical evaluations showed adequate recovery, as good physical activity and good dietary compliance.

\section{Macroscopic evaluation}

The abdominal wall healing was considered adequate in all animals, with no infection, dehiscence, hematoma, abscess, except in one rat of GA, in which partial skin dehiscence occurred without clinical importance. Into abdominal cavity there were not abscess, hematoma, fistula and/or dehiscence.

\section{Adherence gradation (Nair criteria)}

The adherence on day 7 was in grade I in all three groups, two in grade II in GA and GB and one in grade III in GB, with no significant difference in the $7^{\text {th }}$ and $14^{\text {th }}$ days. However, significant difference was observed at day $21(\mathrm{p}=0.014$, Table 1$)$.

TABLE 1 - Inter-group evaluation in different post operative days concerning to adherence.

\begin{tabular}{cccccc}
\hline Day & Nair $^{37}$ & \multicolumn{3}{c}{ Group } & p \\
& & Control & Aroeira & Babassu & \\
\hline 7 & 0 & $0(0.0)$ & $1(16.7)$ & $0(0.0)$ & 0.638 \\
& I & $3(50.0)$ & $3(50.0)$ & $3(50.0)$ & \\
& II & $3(50.0)$ & $2(33.3)$ & $2(33.3)$ & \\
& III & $0(0.0)$ & $0(0.0)$ & $1(16.7)$ & \\
14 & I & $1(16.7)$ & $2(33.3)$ & $2(33.3)$ & 0.126 \\
& II & $2(33.3)$ & $4(66.7)$ & $4(66.7)$ & \\
& III & $3(50.0)$ & $0(0.0)$ & $0(0.0)$ & \\
& 0 & $1(16.7)$ & $1(16.7)$ & $0(0.0)$ & $\mathbf{0 . 0 1 4}$ \\
& I & $4(66.7)$ & $0(0.0)$ & $0(0.0)$ & \\
In & II & $1(16.7)$ & $5(83.3)$ & $6(100.0)$ & \\
& 0 & $1(5.6)$ & $2(11.1)$ & $0(0.0)$ & 0.195 \\
& I & $8(44.4)$ & $5(27.8)$ & $5(27.8)$ & \\
& II & $6(33.3)$ & $11(61.1)$ & $12(66.7)$ & \\
& III & $3(16.7)$ & $0(0.0)$ & $1(5.6)$ & \\
\hline
\end{tabular}

Test: Kruskal Wallis. Significance level $\mathrm{p}<0.05$

Adhesions between an organ and abdominal wall or between two organs were found in eight GC rats and in five GA and GB (Figure 2).

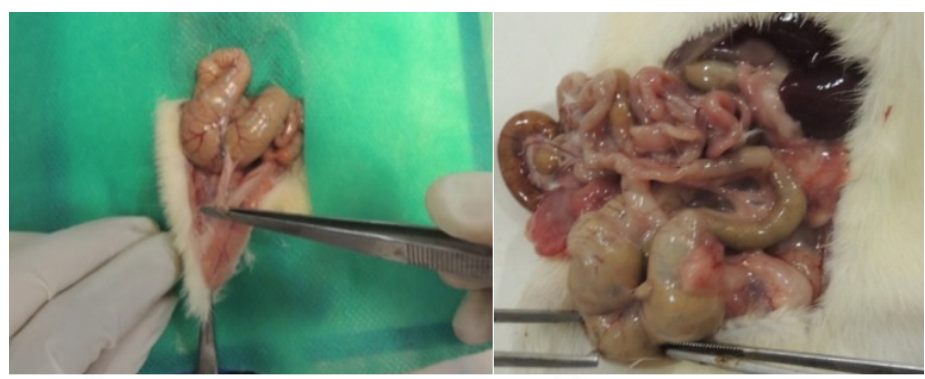

A

B

FIGURE 2 - Examples of adhesions between organs and abdominal wall. A) Grade I; B) Grade III.

In $\mathrm{GB}$ one rat showed widespread adhesion without adhering to the abdominal wall (Nair III) on day 7 (Figure 3B). At day 21 was evidenced grade II in all GB animals and in great amount on GA, while in the GC it was observed in only one animal, with significant difference $(\mathrm{p}=0.014)$. 


\section{Resistance evaluation (air insufflation test)}

The mean values of burst pressure were evaluated by chi-square test, observing progressive increase in GA according to the days and decreasing in GB. However, no significant difference between the groups was achieved (Figure 3).

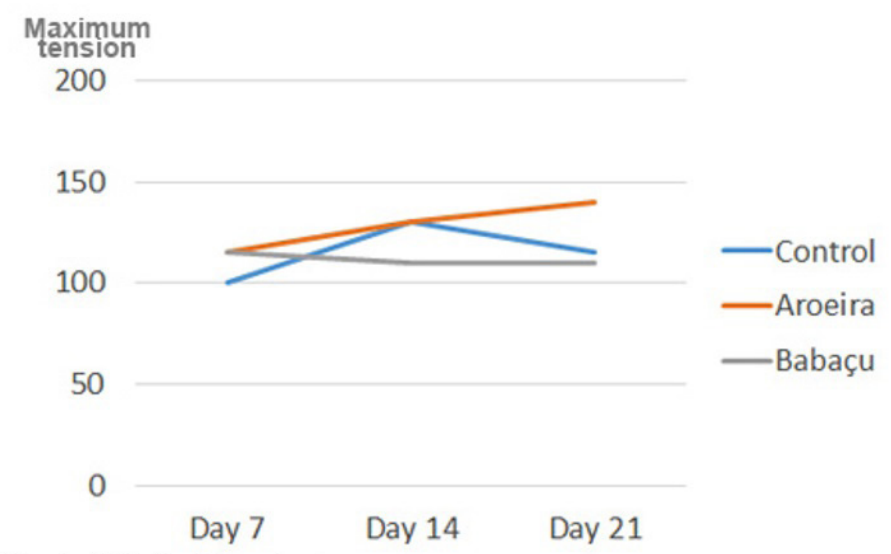

Kruskal Wallis. Dunn test

FIGURE 3 - Mean values of burst pressure in the colon.

The resistance test to air insufflation was performed in all rats, uneventfully. In control animals, on day 7 , the break point was within the suture in five; four animals on day 21 had rupture outside the suture. In GB there was no difference compared to days. In the GA on the $21^{\text {st }}$ day, the break was out of the suture in all animals, showing significant difference $(\mathrm{p}=0.049)$ (Table 2$)$.

TABLE 2 - Breaking point according to post operative day (intra-group).

\begin{tabular}{ccccc}
\hline Days & Group & \multicolumn{2}{c}{ Rupture site } & p \\
Out of the & On the & \\
suture & suture & \\
\hline Control & 7 & 1 & 5 & 0.135 \\
& 14 & 4 & 2 & \\
Aroeira & 21 & 4 & 2 & \\
& 7 & 4 & 2 & $\mathbf{0 . 0 4 9}$ \\
& 14 & 2 & 4 & \\
Babassu & 21 & 6 & 0 & \\
& 7 & 4 & 2 & 1.000 \\
& 14 & 4 & 2 & \\
& 21 & 4 & 2 & \\
\hline
\end{tabular}

Test: chi-square - Pearson. Level of significance $\mathrm{p}<0.05$

\section{Microscopic evaluation}

In Kruskal Wallis histological variances in relation to the day within the groups (inter-group) there was significant difference on day 14 (Table 3 ).

TABLE 3 - Variances related to histology, according to the post operative day within inter-group.

\begin{tabular}{|c|c|c|c|c|c|}
\hline \multirow[t]{2}{*}{ Day } & & \multicolumn{3}{|c|}{ Group } & \multirow[t]{2}{*}{$\mathbf{p}$} \\
\hline & & Control & Aroeira & Babassu & \\
\hline \multirow[t]{8}{*}{7} & $\begin{array}{l}\text { Polymorpho- } \\
\text { nuclear }\end{array}$ & $\begin{array}{l}\text { Mod./ } \\
\text { Accent. }\end{array}$ & $\begin{array}{l}\text { Mod./ } \\
\text { Accent. }\end{array}$ & Accent. & 0.385 \\
\hline & $\begin{array}{l}\text { Monomor- } \\
\text { phonuclear }\end{array}$ & $\begin{array}{l}\text { Mod./ } \\
\text { Accent. }\end{array}$ & Accent. & Mod. & 0.057 \\
\hline & Edema & Mod. & Mod. & Mod. & 0.322 \\
\hline & Congestion & $\begin{array}{l}\text { Mod./ } \\
\text { Accent. }\end{array}$ & Accent. & Accent. & 0.150 \\
\hline & Angiogenesis & Mod. & Accent. & Mod./ & 0.533 \\
\hline & $\begin{array}{c}\text { Fibroblast } \\
\text { proliferation }\end{array}$ & $\begin{array}{c}\text { Mod./ } \\
\text { Accent. }\end{array}$ & Accent. & $\begin{array}{l}\text { Accent. } \\
\text { Accent. }\end{array}$ & 0.123 \\
\hline & Fibrosis & Slight & Slight & Abs & 0.189 \\
\hline & Collagen & Slight & Slight & $\begin{array}{l}\text { Abs/ } \\
\text { Slight }\end{array}$ & 0.284 \\
\hline \multirow[t]{8}{*}{14} & $\begin{array}{l}\text { Polymorpho- } \\
\text { nuclear }\end{array}$ & Mod. a & $\begin{array}{c}\text { Slight/ } \\
\text { Mod. ab }\end{array}$ & Abs $\mathbf{b}$ & 0.004 \\
\hline & $\begin{array}{l}\text { Monomor- } \\
\text { phonuclear }\end{array}$ & Accent. & $\begin{array}{l}\text { Mod./ } \\
\text { Accent. }\end{array}$ & $\begin{array}{l}\text { Slight/ } \\
\text { Mod. }\end{array}$ & 0.104 \\
\hline & Edema & Mod. & $\begin{array}{l}\text { Slight/ } \\
\text { Mod. }\end{array}$ & $\begin{array}{l}\text { Slight/ } \\
\text { Mod. }\end{array}$ & 0.809 \\
\hline & Congestion & Accent. $\mathbf{a}$ & Mod. b & Slight c & 0.004 \\
\hline & Angiogenesis & Mod. a & Mod./ & Slight $\mathbf{b}$ & 0.011 \\
\hline & $\begin{array}{c}\text { Fibroblast } \\
\text { proliferation }\end{array}$ & $\begin{array}{c}\text { Accent. } \\
\mathbf{a}\end{array}$ & $\begin{array}{l}\text { Accent. a } \\
\text { Accent. a }\end{array}$ & Mod. b & 0.030 \\
\hline & Fibrosis & Slight & Slight & Abs & 0.056 \\
\hline & Collagen & Slight a & Slight a & Abs b & $\mathbf{0 . 0 3 3}$ \\
\hline \multirow[t]{8}{*}{21} & $\begin{array}{l}\text { Polymorpho- } \\
\text { nuclear }\end{array}$ & $\begin{array}{c}\mathrm{Abs} / \mathrm{Sli}- \\
\mathrm{ght}\end{array}$ & Slight & Slight & 0.414 \\
\hline & $\begin{array}{l}\text { Monomor- } \\
\text { phonuclear }\end{array}$ & Mod. & Mod. & Mod. & 0.087 \\
\hline & Edema & Slight & $\begin{array}{l}\text { Slight/ } \\
\text { Mod. }\end{array}$ & Mod. & 0.533 \\
\hline & Congestion & Mod. & Mod. & Mod. & 0.812 \\
\hline & Angiogenesis & Slight/ & Slight/ & Slight & 0.757 \\
\hline & $\begin{array}{c}\text { Fibroblast } \\
\text { proliferation }\end{array}$ & $\begin{array}{c}\text { Mod. } \\
\text { Accent. }\end{array}$ & $\begin{array}{l}\text { Mod. } \\
\text { Accent. }\end{array}$ & Accent. & 0.298 \\
\hline & Fibrosis & $\begin{array}{l}\text { Abs/ } \\
\text { Slight }\end{array}$ & Abs & Abs & 0.492 \\
\hline & Collagen & $\begin{array}{l}\text { Abs/ } \\
\text { Slight }\end{array}$ & Slight & Abs & 0.533 \\
\hline
\end{tabular}

Test: Kruskal Wallis. Legend: $\mathrm{a}, \mathrm{b}$ and $\mathrm{c}$ refer to $\mathrm{p}<0.05$; Accent. $=$ accentuated Mod. $=$ moderate; Slight $=$ slight $;$ Abs $=$ absent 
Regarding the presence of polymorphonuclear, it was observed significant difference on day $14^{\text {th }}$ between the GC and GB (Table 4).

TABLE 4 - Detailed inter-group histological analysis.

\begin{tabular}{|c|c|c|c|c|c|}
\hline & $\begin{array}{c}\text { Day/ } \\
\text { Group }\end{array}$ & GC & GA & GB & $\mathbf{p}$ \\
\hline \multirow{3}{*}{$\begin{array}{l}\text { Polymor- } \\
\text { phonuclear }\end{array}$} & 7 & $\begin{array}{l}\text { Mod./ } \\
\text { Accent. }\end{array}$ & $\begin{array}{l}\text { Mod./Ac- } \\
\text { cent. }\end{array}$ & Accent. & 0.385 \\
\hline & 14 & Mod. a & $\begin{array}{l}\text { Slight/ } \\
\text { Mod. ab }\end{array}$ & Abs $\mathbf{b}$ & $0.004 \%$ \\
\hline & 21 & $\begin{array}{l}\text { Abs/ } \\
\text { Slight }\end{array}$ & Slight & Slight & 0.414 \\
\hline \multirow{3}{*}{ Edema } & 7 & Mod. & Mod. & Mod. & 0.322 \\
\hline & 14 & Mod. & $\begin{array}{l}\text { Slight/ } \\
\text { Mod. }\end{array}$ & $\begin{array}{l}\text { Slight/ } \\
\text { Mod. }\end{array}$ & 0.809 \\
\hline & 21 & Slight & $\begin{array}{l}\text { Slight/ } \\
\text { Mod. }\end{array}$ & Mod. & 0.533 \\
\hline \multirow{3}{*}{ Congestion } & 7 & $\begin{array}{l}\text { Mod./ } \\
\text { Accent. }\end{array}$ & Accent. & Accent. & 0.150 \\
\hline & 14 & $\begin{array}{l}\text { Accent. } \\
\mathbf{a}\end{array}$ & Mod. b & Slight c & 0.004 \\
\hline & 21 & Mod. & Mod. & Mod. & 0.812 \\
\hline \multirow{3}{*}{$\begin{array}{l}\text { Monomor- } \\
\text { phonuclear }\end{array}$} & 7 & $\begin{array}{l}\text { Mod./ } \\
\text { Accent. }\end{array}$ & Accent. & Mod. & 0.057 \\
\hline & 14 & Accent. & $\begin{array}{l}\text { Mod./ } \\
\text { Accent. }\end{array}$ & $\begin{array}{l}\text { Slight/ } \\
\text { Mod. }\end{array}$ & 0.104 \\
\hline & 21 & Mod. & Mod. & Mod. & 0.087 \\
\hline \multirow{3}{*}{$\begin{array}{l}\text { Angioge- } \\
\text { nesis }\end{array}$} & 7 & Mod. & Accent. & $\begin{array}{l}\text { Mod./ } \\
\text { Accent. }\end{array}$ & 0.533 \\
\hline & 14 & Mod. a & $\begin{array}{c}\text { Mod./ } \\
\text { Accent. a }\end{array}$ & $\begin{array}{c}\text { Slight } \\
\text { b }\end{array}$ & 0.011 \\
\hline & 21 & $\begin{array}{l}\text { Slight/ } \\
\text { Mod. }\end{array}$ & $\begin{array}{l}\text { Slight/ } \\
\text { Mod. }\end{array}$ & Slight & 0.757 \\
\hline \multirow{3}{*}{$\begin{array}{c}\text { Fibroblast } \\
\text { prolifera- } \\
\text { tion }\end{array}$} & 7 & $\begin{array}{l}\text { Mod./ } \\
\text { Accent. }\end{array}$ & Accent. & Accent. & 0.123 \\
\hline & 14 & $\begin{array}{l}\text { Accent. } \\
\text { a }\end{array}$ & Accent. a & Mod. b & 0.030 \\
\hline & 21 & Accent. & Accent. & Accent. & 0.298 \\
\hline \multirow{3}{*}{ Fibrosis } & 7 & Slight & Slight & Abs & 0.189 \\
\hline & 14 & Slight & Slight & Abs & 0.056 \\
\hline & 21 & $\begin{array}{l}\text { Abs/ } \\
\text { Slight }\end{array}$ & Abs & Abs & 0.492 \\
\hline \multirow{3}{*}{ Collagen } & 7 & Slight & Slight & $\begin{array}{l}\text { Abs/ } \\
\text { Slight }\end{array}$ & 0.284 \\
\hline & 14 & Slight a & Slight a & Abs b & 0.033 \\
\hline & 21 & $\begin{array}{l}\text { Abs/ } \\
\text { Slight }\end{array}$ & Slight & Abs & 0.533 \\
\hline
\end{tabular}

Test: Kruskal Wallis. Legend: $\mathrm{a}, \mathrm{b}$ and $\mathrm{c}$ refer to $\mathrm{p}<0.05$; Accent. $=$ accentuated; Mod.=moderate; Slight $=$ slight; Abs $=$ absent
Polymorphonuclear cells were found in the GC and GB with moderate and absent intensity, respectively. Edema was present with moderate intensity in all groups except GC on day 21 that was discrete, with no significant difference between groups (Table 4).

Congestion was observed with increased intensity in the three groups on day 7 with no significant difference between groups at 7 and 21 days. However, significant differences between the three groups were found on day $14(p=0.004$, Table 4$)$.

The mononuclear cells were observed with increased intensity on day 7 in GA and GC on the $14^{\text {th }}$ day, being discrete in $\mathrm{GB}$ on the $14^{\text {th }}$ day, with no significant difference between groups (Table 4).

Regarding angiogenesis, a significant difference was evident at 14 days between the GC, and GA with GB, with no difference between the first two (Table 4), with mild and moderate/ severe intensity in GA and GB, respectively).

Fibroblast proliferation had significant difference at 14 days between the GC and GB, with severe and moderate intensity, respectively ( $p=0.03$ ) (Table 4$)$. On the other days, the variable appeared with increased intensity.

Fibrosis was observed discrete or absent in all groups and days, showing no significant difference between them (Table 4).

Regarding the presence of collagen was similar to fibrosis, but significant difference was observed on day 14 between GC and GA with GB ( $\mathrm{p}=0.033$ ), with no difference between the first two (Table 4). The collagen was evident in GC and GA discreetly and absent in GB.

\section{Discussion}

This study was done using only male rats to avoid influences of the hormonal cycle of females ${ }^{18}$. The days of death were chosen based on the studies of Goes et al. ${ }^{19}$ on the healing of colonic anastomoses in rats killed at intervals of 3, 7, 14 and 21 days. Baldez et al. ${ }^{18}$ and Ferreira et al. ${ }^{20}$ chose as death periods 3 and 7 days postoperatively. Considering these differences, were used in this study 7,14 and 21 days for scheduled death, since between the $3^{\text {rd }}$ and the $7^{\text {th }}$ days the healing process is quite similar, and at 21 days there is real surgical healing, allowing true comparison.

\section{Herbal choice and route of administration}

The aroeira has popular use in home treatment; may be administered orally or topically for curing various diseases. The 
reason that influenced its choice was easy extraction, preparation, drying, grinding, storage and application ${ }^{21}$, and also because its current use as medicine herbal, though without scientific confirmation $^{8,16}$.

Preclinical studies in mice showed that the extract of babassu mesocarp had beneficial effect on several circumstances ${ }^{22}$. It is used as food and in the treatment of various diseases; it has a wide distribution in Maranhão state in Brazil.

The dose chosen was based on other studies referring better results with $50 \mathrm{mg} / \mathrm{kg}$ of babassu extract ${ }^{23}$ and $100 \mathrm{mg} /$ $\mathrm{kg}$ of the aqueous extract of aroeira ${ }^{16}$. Already the oral route of administration by daily gavage ${ }^{24,25}$ differs from other papers ${ }^{23,26}$ using it parenterally, intraperitoneally and even topically in different dosages, proving that this herbal can be used by different administration routes. Was considered by the authors of this study that daily administration would give better action opportunity and could contribute to the literature with alternative higher dosage.

\section{Macroscopic evaluation and adherence gradation}

Macroscopy, regarding complications (infection, dehiscence, fistula, hematoma, abscess, both on the wall and in the abdominal cavity), showed no complications except for one GC rat with wound partial dehiscence; however, this fact did not demonstrate significant difference between groups ${ }^{8,27}$.

Adherence can be observed as a result of trauma to the peritoneal surface of the intra-abdominal organs promoting inflammatory reaction, followed by increased vascular permeability and releasing rich fibrin exudate. Adhesions were observed in all groups and in all days, but only significant on day 21 in GB wherein all rats had adhesion type II, but without significant difference. But Lucena et al. ${ }^{9}$ found significant differences more often in GA than in the GC on the $7^{\text {th }}$ day. In this research, although without significance, on the $14^{\text {th }}$ day, it can be inferred that there was favoritism for GA and GB, as these groups had lower adhesion degrees compared to GC.

\section{Tensiometric evaluation (resistance to air insuffla- tion)}

According to Santos et $a l .{ }^{10}$, the mechanical strength of the scar through the resistance to air insufflation test is one of the main parameters for assessing the integrity of the anastomoses in the early postoperative days. As hollow viscus, this test is to reproduce physiological pressure vectors that normally are transmitted to the wall, with clinical simulation, since the breakup will occur depending on the distention.
The burst pressure is significantly lower in the early postoperative days, compared to 7 and 14 days, since the initial anastomose resistance is more dependent on sutures, being the late stage to collagen deposition.

In this research, was observed a progressive increase in burst pressure values in GA according to days, decreasing in GB. In $\mathrm{GC}$, this pressure increased on day 14 and decreased on day 21 , all without significant difference. Despite studies of Lucena et al. ${ }^{9}$ and Coutinho et $a l{ }^{8}$ did not show significant difference, the burst pressure increased with the days. This result may be justified due to the fact that these authors evaluated only until the $7^{\text {th }}$ day.

Petroianu et al..$^{28}$ emphasized that anastomose strength in the late period, after the $14^{\text {th }}$ day, is best assessed by linear traction dynamometers with precision in the range of isolated tissue.

Unlike the study by Santos et $a l^{25}$ in which the rupture site on insufflation test occurred in specific point of the suture line (weakest point), it can be inferred that in this site young collagen predominated; in this study, rupture occurred both inside and outside of suture site, with a significant difference in GA at day 21 , when all were outside.

\section{Histological evaluation}

In this study, histological assessment used the technique of hematoxylin and eosin staining, where different histological variables are quantified and classified according to the presence and intensity, establishing the classification of healing in acute and chronic inflammation. The presence of vascular congestion, edema and polymorphonuclear were indicative of acute inflammation (acute or inflammatory phase of the healing process). The presence of mononuclear cells, angiogenesis, fibroblast proliferation, fibrosis (collagen deposition) and collagen were indicative of chronic inflammation (chronic or proliferative phase of the healing process). To evaluate the presence of collagen fibers in the area of healing, the technique of Masson trichrome staining was used, although it is not free of criticism for not differentiate collagen from the point of view of quality but quantity. These techniques were used because they are consolidated ${ }^{19,20,29}$.

The tissue injury healing by first intention causes death of epithelial cells and connective tissue, promoting continuity solution on epithelial basement membrane. The area of the lesion is filled with blood clots, fibrin and white blood cells, approximately $24 \mathrm{~h}$ with a peak of up to five days, migrating neutrophils (polymorphonuclear leukocytes) to the edge of the incision to remove crusts - the phagocytosis. The intestinal wall becomes increasingly thickened by increasing vascular 
permeability (congestion) and causing edema, and the migration of large numbers of acute inflammatory cells.

Regarding the presence of polymorphonuclear cells, significant difference was observed on day 14 between the GC and $\mathrm{GB}$, being moderate and absent, respectively. On the $7^{\text {th }}$ day, groups showed be moderate to severe in most animals, contradicting the study of Coutinho et al. ${ }^{8}$ and Santos et al. ${ }^{10}$ that referred discrete to moderate.

Similar to other papers ${ }^{8,27}$ for the presence of edema, here it was found to be moderate in all groups except on GC day 21 (discrete) without significant difference. However, in other studies ${ }^{18,30}$ it was seen sparingly on the $7^{\text {th }}$ day of GB, with significant difference. Importantly, in all three compared studies the evaluation was on $7^{\text {th }}$ day.

Another important acute inflammatory variable is the histological vascular permeability or congestion. It performed with marked intensity on day 7 , consistent with the initial acute phase, there was no significant difference between groups. However, on day 14 there was a significant difference between the GC and GB, where the latter was discrete ${ }^{18,27}$.

Acute inflammation to some degree is necessary for good response of tissue repair (wound healing); however, intense inflammatory reaction may decrease the blood supply with consequent inhibition of fibroblastic proliferation ${ }^{29}$.

Acute exudate is gradually replaced by mononuclear cell infiltration (macrophages and lymphocytes) and granulation (angiogenesis and fibroblasts), and deposition of collagen produced by fibroblasts in the margins of the incision, initiates the chronic inflammatory process.

With respect to mononuclear cells, was observed in this study to be moderate to marked in all groups and in all days, with marginal significant difference noted on day 7 between GA and GB. Studies of Lucena et al. ${ }^{9}$ and Santos et al. ${ }^{25}$ showed intensity on day 7 of chronic inflammation favoring the experimental group with a significant difference in angiogenesis variable. In the present study, there was significant difference on day 14 in GC and GA. Santos et al.$^{24}$ found no difference between groups. Batista et $a l .^{29}$ have published significant trend for the experimental group (babassu), suggesting that longer observation could point to advantages of using herbal medicine.

Some degree of inflammation is necessary; however, if intense is harmful, by impairment the microcirculation and also inhibiting cell proliferation (formation of fibroblasts) ${ }^{9}$. In relation to fibroblast proliferation, there was a significant difference at 14 days between the GC and GB, favoring GC and GA, similar to other studies ${ }^{24,25}$. Another important variable to assess the chronic inflammatory process is fibrosis or collagen deposition. In this research it was observed to be missing/discrete in all groups without significant difference; other studies showed significant differences favoring the experimental group ${ }^{26,27}$ and, in contrast, favoring the $\mathrm{GC}^{24}$. In the gastrointestinal tract, collagen is synthesized by fibroblasts and smooth muscle cells, predominantly in the scar collagen type I (68\%) that plays an important role in the tensile strength of the scar ${ }^{18}$. In this study it was evaluated quantitatively, showing significant difference at 14 days, confirming prior studies $^{27,30}$.

Several are the medicinal actions of aroeira and babassu. Continuity of experimental studies must be based on the use fractions of these herbal, as well as use of other routes of administration, different dosages, longer observation and use of immunohistochemistry in order to better assess their healing actions.

\section{Conclusion}

Hydroalcoholic extract of Schinus terebinthifolius Raddi (aroeira) and the aqueous extract of Orbignya phalerata Mart. (babassu) favored the healing process in cecorrahphy in rats.

\section{References}

1. Campos ACL, Borges-Branco A, Groth AK. Cicatrização de feridas. Arq Bras Cir Dig. 2007 Jan/Mar;20(1):51-8. doi: 10.1590/S010267202007000100010 .

2. Nery RA, Kahlow BS, Skare TL, Tabushi FI, Castro Ado A. Uric acid and tissue repair. Arq Bras Cir Dig. 2015 Dec;28(4):290-2. doi: 10.1590/S0102-6720201500040018.

3. Yasojima EY, Teixeira RK, Houat Ade P, Costa FL, Yamaki VN, Feitosa-Junior DJ, Silva CA, Brito MV. Copaiba oil influences ventral hernia repair with Vicryl ${ }^{\circledR}$ mesh? Arq Bras Cir Dig. 2015 Sep;28(3):186-9. doi: 10.1590/S0102-67202015000300010.

4. Magalhães MA, Petroianu A, Martins SG, Resende V, Alberti LR, Barbosa AJ, Vasconcellos LS, Tavares Junior WC. Closure of large wounds using rubber bands in rabbits. Rev Col Bras Cir. 2015 JanFeb;42(1):56-61. doi: 10.1590/0100-69912015001011.

5. Tazima MFGS, Vicente YAMVA, Moriya T. Biologia da ferida e cicatrização. Medicina (Ribeirão Preto). 2008;41(3):259-64. doi: 10.11606/issn.2176-7262.v41i3p259-264.

6. Isaac C, Ladeira PRS, Rêgo FMP, Aldunate JCB, Ferreira MC. Processo de cura das feridas: cicatrização fisiológica. Rev Med (São Paulo). 2010 Jul-Dez;89(3/4):125-31. doi: 10.11606/issn.16799836.v89i3\%2f4p125-131.

7. Baffa LP, Garcia RLS, Campos AD, Rocha JJR, Feres O. Efeito da anemia aguda na cicatrização de anastomoses colônicas: estudo experimental em ratos. Rev Bras Coloproctol. 2005;25(1):24-30.

8. Coutinho IH, Torres OJ, Matias JE, Coelho JC, Stahlke Júnior HJ, Agulham MA, Bachle E, Camargo PA, Pimentel SK, de Freitas AC. Schinus terebinthifolius Raddi and it's influence in the healing process of colonic anastomosis: experimental study in rats Acta Cir Bras. 2006;21(Suppl 3):49-54. PMID: 17293937. 
9. Lucena PL, Ribas Filho JM, Mazza M, Czeczko NG, Dietz UA, Correa Neto MA, Henriques GS, Santos OJ, Ceschin AP, Thiele ES. Evaluation of the aroreira (Schinus terebinthifolius Raddi) in the healing process of surgical incision in the bladder of rats. Acta Cir Bras. 2006;21(Suppl 2):46-51. PMID: 17117277.

10. Santos OJ, Ribas Filho JM, Czeczko NG, Castelo Branco Neto ML, Naufel C Jr, Ferreira LM, Campos RP, Moreira H, Porcides $\mathrm{RD}$, Dobrowolski S. Evaluation of aroeira (Schinus terebinthifolius Raddi) extract on the healing process of gastroraphy in rats. Acta Cir Bras. 2006;21(Suppl 2):39-45.

11. Veiga Junior VF, Pinto AC, Maciel MAM. Plantas medicinais: cura segura? Química Nova. 2005;28(3):519-28. doi: 10.1590/S010040422005000300026.

12. Malafaia $\mathrm{O}$, Campos ACL, Torres $\mathrm{O}$, Goldenberg S. Os fitoterápicos e seu potencial na cicatrização em cirurgia. Acta Cir Bras. 2006;21(Suppl 3):1. doi: 10.1590/S0102-86502006000800001.

13. Queires LCS, Rodrigues LEA. Quantificação das substâncias fenólicas totais em órgãos da aroeira Schinus terebinthifolius Raddi. Braz Arch Biol Technol. 1998;41:247-53. doi: 10.1590/S151689131998000200012.

14. Carlini EA, Duarte-Almeida JM, Tabach R. Antiulcer effect of the pepper trees Shinus terebinthifolius raddi (aroeira-da-praia) and Myracrodruon urundeuva Allemão, Anacardiaceae (aroeira-dosertão). Braz J Pharmacogn. 2010;20(2):140-6. doi: 10.1590/S0102695X2010000200001.

15. Santos ACA, Rossato M, Serafini LA, Bueno M, Crippa LB, Sartori VC, Dellacassa E, Moyna P. Efeito fungicida dos óleos essenciais de Schinus molle L. e Schinus terebinthifolius Raddi, Anacardiaceae, do Rio Grande do Sul. Rev Bras Farmacogn. 2010;20(2):154-9. doi: 10.1590/S0102-695X2010000200003.

16. Nunes JA Jr, Ribas-Filho JM, Malafaia O, Czeczko NG, Inácio CM, Negrão AW, Lucena PL, Moreira H, Wagenfuhr J Jr, Cruz JJ. Evaluation of the hydro-alcoholic Schinus terebinthifolius Raddi (Aroeira) extract in the healing process of the alba linea in rats. Acta Cir Bras. 2006;21(Suppl 3):8-15. PMID: 17293932.

17. Brito NMB, Silva PRF, Silva GCF, Casella SFM, Sampaio ARS, Carvalho RA. Avaliação macroscópica de feridas cutâneas abertas em ratos tratadas com óleo de andiroba. Rev Paraense Med. 2001;15(2)17-22.

18. Baldez RN, Malafaia O, Czeczko NG, Martins NL, Ferreira LM, Ribas CA, Salles Júnior G, Del Claro RP, Santos Lde O, Graça Neto L, Araújo LR. Healing of colonic anastomosis with the use of extract aqueous of Orbignya phalerata (Babassu) in rats Acta Cir Bras. 2006;21 Suppl 2:31-8. PMID: 17117275.

19. Goes AC, Rodrigues LV, Menezes DB, Grangeiro MP, Cavalcante AR. Histologic analysis of colonic anastomotic healing, in rats, under the action of $10 \%$ Aroeira-do-sertão (Myracrodruon urundeuva fr. all.) enema. Acta Cir Bras. 2005 Mar-Apr;20(2):144-51. PMID: 15884715 .

20. Ferreira EC, Matias JE, Campos AC, Tâmbara Filho R, Rocha LC, Timi JR, Sado HN, Sakamoto DG, Tolazzi AR, Soares Filho MP. Surgical bladder wounds treated with Orbignya phalerata aqueous extract: controlled study in rats. Acta Cir Bras. 2006;21 Suppl 3:339. PMID: 17293935.

21. Leite SR, Amorim MM, Sereno PF, Leite TN, Ferreira JA, Ximenes RA. Randomized clinical trial comparing the efficacy of the vaginal use of metronidazole with a Brazilian pepper tree (Schinus) extract for the treatment of bacterial vaginosis. Braz J Med Biol Res. 2011 Mar;44(3):245-52. PMID: 21243318.

22. Azevedo AP, Farias JC, Costa GC, Ferreira SC, Aragão-Filho WC, Sousa PR, Pinheiro MT, Maciel MC, Silva LA, Lopes AS, Barroqueiro ES, Borges MO, Guerra RN, Nascimento FR. Antithrombotic effect of chronic oral treatment with Orbignya phalerata
Mart. J Ethnopharmacol. 2007 Apr 20;111(1):155-9. PMID: 17141996.

23. Brito Filho SB, Matias JE, Stahlke Júnior HJ, Torres OJ, Timi JR, Tenório SB, Tâmbara EM, Carstens AG, Campos RV, Myamoto M. Analysis of healing in the Alba Linea with the use of Orbignya phalerata (babassu) water extract. Controlled study in rats. Acta Cir Bras. 2006;21 Suppl 3:76-88. PMID: 17293940.

24. dos Santos OJ, Barros-Filho AK, Malafaia O, Ribas-Filho JM, Santos RH, Santos RA. Schinus terebinthifolius Raddi (Anacardiaceae) in the healing process of gastrorraphy in rats Arq Bras Cir Dig. 2012 Jul-Sep;25(3):140-6. PMID: 23411801.

25. Santos OJ, Malafaia O, Ribas-Filho JM, Czeczko NG, Santos RH, Santos RA. Influence of Schinus terebinthifolius Raddi (aroeira) and Carapa guianensis Aublet (andiroba) in the healing process of gastrorraphies. Arq Bras Cir Dig. 2013 Jun;26(2):84-91. PMID: 24000017.

26. Gonçalves Filho A, Torres OJ, Campos AC, Tâmbara Filho R, Rocha LC, Thiede A, Lunedo SM, Barbosa RE, Bernhardt JA, Vasconcelos PR. Effect of Passiflora edulis (passion fruit) extract on rats' bladder wound healing: morphological study. Acta Cir Bras. 2006;21 Suppl 2:1-8. PMID: 17117271.

27. Servin SC, Tores OJ, Matias JE, Agulham MA, de Carvalho FA, Lemos R, Soares EW, Soltoski PR, de Freitas AC. Effects of Jatropha gossypiifolia L. (bellyache bush) extract on the healing process of colonic anastomosis: experimental study in rats. Acta Cir Bras. 2006;21 Suppl 3:89-96. PMID: 17293941.

28. Petroianu A, Cavalcante AMT, Fagundes-Pereyra WJ, dos Santos BMR. Tensão de ruptura dos órgãos que constituem o tubo digestivo com e sem o uso de corticóide em camundongos. Rev Col Bras Cir. 2000;27(2):69-82. doi: 10.1590/S0100-69912000000200002.

29. Batista CP, Torres OJ, Matias JE, Moreira AT, Colman D, Lima JH, Macri MM, Rauen RJ Jr, Ferreira LM, de Freitas AC. Effect of watery extract of Orbignya phalerata (babassu) in the gastric healing in rats: morphological and tensiometric study. Acta Cir Bras. 2006;21 Suppl 3:26-32. PMID: 17293934.

30. Bezerra JA, Campos AC, Vasconcelos PR, Nicareta JR, Ribeiro ER, Sebastião AP, Urdiales AI, Moreira M, Borges AM. Extract of Passiflora edulis in the healing of colonic anastomosis in rats: a tensiometric and morphologic study. Acta Cir Bras. 2006;21 Suppl 3:16-25. PMID: 17293933.

\section{Correspondence:}

Christian Lamar Scheibe

Alameda Augusto Stellfeld, 1980

80730-150 Curitiba - PR Brasil

Tel.: (55 41)3240-5488

clscheibe@uol.com.br

Received: Feb 02, 2016

Review: Apr 04, 2016

Accepted: May 05, 2016

Conflict of interest: none

Financial source: none

${ }^{1}$ Research performed at Postgraduate Program in Principles of Surgery, Faculdade Evangélica do Paraná (FEPAR), Universidade Evangélica do Paraná, Hospital de Curitiba, Medical Research Institute, Curitiba-PR, and Hospital São Domingos, Sao Luis-MA, Brazil. Part of Master degree thesis, Postgraduate Program in Principles of Surgery. Tutor: Jurandir Marcondes Ribas Filho. 